\title{
Interregional mobility of talent in Spain: The role of job opportunities and qualities of places during the recent economic crisis
}

\author{
Simón Sánchez-Moral ${ }^{1}$ \\ Complutense University of Madrid, Spain
}

\section{Alfonso Arellano}

Complutense University of Madrid, Spain

Roberto Díez-Pisonero

Complutense University of Madrid, Spain

\begin{abstract}
This paper seeks to extend our knowledge of the drivers behind talented workers' mobility within the Spanish urban system and the patterns they may follow. For this purpose, the stock and flows of creative workers (selected on the basis of either the industry-based or occupational approaches) are studied at different spatial scales while also considering the influence of local characteristics as a source of attracting and retaining forces. The study is based on the analysis of a quite novel longitudinal micro-database from the Spanish Social Security office. Under the conditions of lower mobility of creative workers compared with other geographical contexts -a trend worsened by the economic crisis- we show that job opportunities, especially in connection with workers' social networks, emerge as the most influential attracting factor. Thus, beyond the classic idea that agglomeration economies benefit all residents, we found evidence that the biggest cities, and Madrid in particular, had become "escalator regions", propelling the careers of young creative workers that had been attracted to them. On the contrary, the influence of urban amenities seems limited to the retention of talent. This research aims to contribute to dealing with the challenge of upgrading local productive forces after the economic crisis and to develop tailor-made talent attraction and retention strategies.
\end{abstract}

\section{Keywords}

Creative workers, labour trajectories, mobility, Spanish cities

\footnotetext{
${ }^{1}$ Corresponding author:

Simón Sánchez-Moral, Department of Geography, Faculty of Geography and History, Complutense University of Madrid, c/Profesor Aranguren s/n, Madrid 28040, Spain.

Email: simon.sanchez@ghis.ucm.es
} 


\section{Introduction}

Traced back to the 'classic' perspectives of endogenous growth (Romer, 1986) and some prescient observations regarding the post-industrial society (Bell, 1973), the attraction of 'talent' has become one of the main issues for academics and policymakers concerned with urban development in the context of cultural-cognitive capitalism (Scott, 2008; Musterd et al., 2016). The contribution of skilled workers to local economies is highlighted by all experts, albeit from different definitions (i.e. human capital, knowledge and creative workers); in terms of potential gains in productivity, generation of knowledge spillovers and pecuniary externalities or more investments in knowledge-based activities and innovation (Dahl and Sorensen, 2010); as well as regarding the improvement in the quality of life due to the demand of urban amenities or the upgrading of local institutions (Shapiro, 2006).

As a result, talent migration is today considered one of the driving forces of regional growth (Faggian and McCann, 2009). This concerns not only cities at the top of the urban hierarchy, where the 'war for talent' is frequently alluded to (Faulconbridge et al., 2009), but also small and medium-sized cities, which increasingly get involved in such competitions. In particular, old industrial cities striving to reinvent themselves in the context of global economic restructuring have attracted some of the attention (Kempner, 2008). This was exactly the target of our prior approach to the question (Sánchez- Moral, 2017), which already uncovered some trends that deserve a more holistic and complex analysis at the Spanish urban system level, while considering the scale effects and the role of attracting forces, including forms of spatial and labour mobility in line with the so-called 'escalator model' (Fielding, 1992; Gordon et al., 2015).

The endowment of knowledge and creativity resources in the Spanish regions has been addressed before (e.g., Méndez and Sánchez-Moral, 2011; Navarro et al., 2014). However, many of these studies use a more conventional definition of human capital to analyse stock variables, mainly because of data limitations. On the contrary, the use on this research into longitudinal data from the Spanish Continuous Sample of Working Histories (CSWH) represents an opportunity. A more complex conceptualization of 'talent' can be made, based on the two dominant perspectives in the literature (industry-based and occupational approaches); and it also allows for the analysis of migration variables. Furthermore, the continuous updating of these data makes it possible to examine the impact of the 2008 economic crisis on the phenomena. This might have eroded cities' attractiveness, especially in terms of employment opportunities, which according to most of the evidence is the main attracting factor. In short, this research aims to respond to two general questions:

\section{- What are the different roles of Spanish urban areas and cities within the interregional talent} migration patterns?

- What are the main factors in Spanish urban areas attracting and retaining talent and how has their influence evolved during the economic crisis?

This paper is organized as follows: in the second section, the theoretical bases of the research are presented; the third section includes methodological explanations about CSWH microdata and the local indicators selected; section four contains the analysis of patterns of spatial mobility at different scales, while section five deals with labour mobility and escalator effects. Section six discusses the results of the correlation between migration variables and local conditions indicators. The last section summarizes the main findings and reflects on policy implications. 


\section{Theoretical framework}

\section{Making the 'talent' notion operational through 'creative workers'}

Despite the interest in common in talent as a source of regional growth, there is a lack of agreement on how to define and measure it. The difficulties begin with the closely related notion of 'human capital', which has changed since pioneering studies (Becker, 1964); from conventional measures based on educational attainments to an increasing interest in what people do (Mellander and Florida, 2009). At the same time, Putnam (1993) has stressed the importance of learning environments and social and institutional features that foster individual learning and skills. As a result, there is a widening and blurring of the 'human capital' concept, which in practice comes to mean any knowledge, skills and competences embodied in individuals or their social relations that increase an individual's productivity (Faggian and McCann, 2009).

In this context, we must mention the controversial contribution of Florida, who refers to creative individuals -or talent- and proposes the alternative "creative occupations" measure instead of the more typical educational-based human capital measure (Florida, 2005). This definition of talent to some extent covers the two approaches that have finally dominated the debate: the industry-based approach (understanding creativity as a corporate asset) and the occupational approach (as an attribute of the workforce) (Cruz and Texeira, 2013).

The former criterion alludes to certain sectors that, in general, produce and use knowledge more intensively, exhibit higher innovation rates and demand more qualified professionals: namely, industries of high technological intensity; knowledge-intensive services, including business services; and cultural industries ( $\mathrm{Wu}, 2005)$. Within the occupational approach, different contributions about 'knowledge workers' (Stehr, 2002) or the well-known 'creative class' (Florida, 2005) have centred the interest on some professional and technical classes, generally associated with a higher level of education (i.e. designers, architects, artists, craft workers, publicists, programmers, actors, among others).

From among the broad criticism of Florida's theses (see for example Boschma and Fritsch, 2009) of special relevance for our study is the concern about the heterogeneity of individuals included within his broad definition of creative class. According to Krätke (2010), this may have more to do with a 'dealer class' in finance and real estate and with an 'economic management class' than with any other 'class', such as that of bohemians and artists. Furthermore, Krätke and other authors differentiate between scientifically, technologically and artistically creative workers. The attempt to control heterogeneity has led to recent proposals such as the so-called "creative trident" (Higgs et al. 2008) and "creative and knowledge workers" (Musterd et al., 2016), focussed on highly-skilled workers within the activities of reference.

All in all, this worker heterogeneity may influence workers' lifestyles, including patterns of mobility, responsiveness to attracting forces and, in turn, the uneven impact of development on the regional economy in terms of innovation and growth (Gabe and Aber, 2011).

\section{Interregional migration determinants of creative workers}

The diversity of theoretical approaches makes it necessary to consider a number of contributions of talent mobility determinants. Understanding migration as an individual's choice of investments in human capital based on expected returns and costs, (micro) economic-based approaches consider personal characteristics to drive the migration process 
(Delisle and Shearmur, 2010). As Herbst and Rok (2013) summarise the propensity to migrate decreases with age, while women seem initially less prone to migrate or more conditioned by couples' decisions and family support (also by lower expectations from migration due to salary gap). At the same time, it seems clear that workers educated in a different region of birth, or even in a different country, display a higher propensity to migrate since after a first migration subsequent movements are more likely (Da Vanzo and Morrison, 1981).

Nevertheless, qualifications play a crucial role, mediating among many of the abovementioned effects. Sjaastad (1962) suggested a link between long periods of unemployment for low-skilled workers and low-income groups and the risk of becoming 'locked into' an immobile situation (especially in lagging regions). On the contrary, the willingness to move seems clearly greater in young and skilled workers, which explains why local labour inputs are generally of lower-skilled human capital than those sourced from other regions (Faggian and McCann, 2009). On the contrary, some other authors argue that qualified people may have a greater chance of being employed in their regions, so under certain circumstance their migration propensity declines (Shioji, 2001).

A second (macro) economic-based approach, built on 'classic' endogenous growth theories (Romer, 1986), conceives human capital flow as an aggregated outcome of individual decisions ${ }^{1}$. According to Faggian and McCann (2009), specific destination regions -dominant cities- increasingly benefit from net inflows of highly qualified individuals at the expense of other source regions, which simultaneously exhibit net outflows -basically regions with a declining population. However, in a second scenario, net inflows of particular types of qualified individuals would tend to replace people from other groups that exhibit net outflows from the same region; mainly, young and low-wage workers versus older, more educated and higher wage individuals who prefer living outside of the inner city. Such an explanation corresponds with the so-called 'escalator model', which interprets the phenomenon in terms of social mobility and human capital acquisition processes that simultaneously maintain the continuous flow of ideas and knowledge to cities (Faggian et al., 2007).

The understanding of these inter-regional migration patterns makes it necessary to pay attention to the regional characteristics, as a source of push and pull factors. The economic and urban geography disciplines have made very valuable contributions to this question. According to Musterd and Murie (2010), a first set of 'hard' or 'classic' conditions influence the location of firms; i.e. availability of capital, transport and communications, job opportunities or the institutional context (regulations, tax policies, labour legislation, etc.). The cost of living (i.e. housing prices) would be a 'hard' factor for workers (Musterd et al., 2016). Second, under certain circumstances some firms may benefit from 'cluster' economies. A third group, more connected with the attraction of workers, relates to 'soft conditions'. Some of these are concerned in the ongoing debate about the role of qualities of places and urban amenities (recent good reviews of the topic can be found for example in Miguélez and Moreno, 2014; Bontje et al., 2017). As part of the main two approaches, Glaeser (2005) underlines the role of public and social services and the vibrant cultural and historical scene; while Florida (2005) highlights tolerance, openness and diversity of population, including the presence of talented workers, as well as seeking certain values of 'distinctiveness' and 'authenticity' in neighbourhoods. Fourth, local 'personal and social networks' related to where individuals grew up or studied deserves increasing attention (Dahl and Sorensen, 2010; Cooke, 2014).

Previous evidence suggests that job opportunities, as well as personal and social networks, could be the most important factor for attracting talented individuals, while soft factors seem to be more significant when it comes to retaining them (Musterd and Murie, 2010; Miguélez 
and Moreno, 2014). In fact, the existence of certain types of job opportunities at some specific places is crucial in the initial 'escalator' hypothesis of Fielding (1992). More recently, a distinction has been made between 'escalator' effects, experienced by residents of cityregions favoured by pure agglomeration economies and the concentration of more dynamic industries, and 'elevator effects', experienced by migrants, reflecting inter-regional variations in the pressure of labour demand. As a result, a combination of personal and contextual factors would explain the higher rates of occupational progression in some 'escalator regions'; namely, the ambitions of young individuals and also the particular role of 'practice communities' in providing them with access to the premium (in terms of occupations or earnings gains), according to workers' capability and their networks (Gordon et al., 2015).

In this regard, high-order cities -specially global cities - may offer the right job opportunities thanks to their position within global knowledge networks and the concentration of most dynamic activities and non-routine and highly skilled labour-intensive tasks in the context of the new spatial division of labour (Levy and Murnane, 2004; Findlay et al., 2008; Storper and Scott, 2009).

\section{Data and methods}

The Continuous Sample of Working Histories (CSWH) is a set of anonymous microdata obtained from a random non-stratified sample of persons who have been registered in the Spanish Social Security system during the reference year and those who receive some type of contributory pension. The sample is made up of 4 per 100 people from the reference population $^{2}$. The initial sample was 788,646 workers ${ }^{3}$.

The contracts' information has been used to identify the workers according to the two criteria explained in the previous section ${ }^{4}$. The application of the industry-based approach requires the prior identification of the workers' main activity, on the basis of the most recent and longest contract in force. Then a comprehensive classification of knowledge-intensive and creative industries has been used $^{5}$ (see Musterd et al., 2007 for further explanations). Meanwhile, what we called 'creative occupations' was identified by means of the socioprofessional category recognized by the employer. In particular, the two highest categories were selected: 'Engineers, university graduates, senior management' and 'Technical engineers, qualified assistants'. As this variable is only available for salaried workers, selfemployed workers were left out of the analysis when the socio-professional criterion category is applied ${ }^{6}$.

In short, the 'creative workers' label has been used throughout the text to refer indistinctly to workers in knowledge-intensive and creative industries and workers in creative occupations.

Other variables in the CSWH have also been used to characterize the socio-professional profiles of workers (i.e. age, gender, place of birth, education level and salaries ${ }^{7}$ ). On the other hand, when the workers' histories lack information about the location of working centres (typically among self-employed workers), then the residence location data were used. The analysis has been conducted at both municipal level (although records for cities below the threshold of 40,000 inhabitants are not classified in the CSWH) and at Large Urban Areas level $^{8}$ (LUAs).

In view of the statistical distribution of the variables, the correlation between the stock and flows of creative workers and the local characteristics was limited to the non-parametric test of Spearman's rho. This yielded results that were relevant to the objectives of the study. Taking into account previous discussions and the scarcity of information at the local level, the following indicators were finally selected within each category: 
a. 'Hard factors' has been approached in different ways, beginning with the local population size. The Economic Activity Index captures the share of the municipality on the total country collecting of taxes for economic and professional activities (excluding agriculture). The unemployment rate is calculated as the percentage of unemployed workers registered over the active population between 15-65 years old. The share of permanent contracts is calculated on the basis of the total contracts signed during the year. The number of ISDN and ADSL lines per 1,000 inhabitants and non-subsidised housing prices have also been considered.

b. 'Cluster factors' have been approached by means of the weight of local employment in three innovative clusters: manufactures of high technological intensity (NACE codes: 24, 30, 32, 33 and 35), Knowledge-based services (65-67, 72-74, 80 and 85) and Other creative sectors (22 and 92).

c. 'Soft conditions' includes different proxy variables: the share of residents with tertiary education, the share of foreign-born residents, the non-subsidised housing prices and the percentage of houses less than ten years old. In addition, the local Retail Activities Index, based on the mentioned Economic Activity Index, has been considered as well as the supply of cultural and leisure activities in terms of employment (NACE codes: 561, 563, 591, 592, 601, 602, 900, 910, 931 and 932). The percentage of houses less than ten years old may approximate the degree of 'authenticity'/ renovation of the urban space.

d. 'Network factors' are especially affected by the statistical deficit. Considering the 'escalator/ elevator' effects in terms of the access to specific job opportunities that permit acquiring tacit knowledge and connections (i.e. social networks), provided by particular communities to their most ambitious individuals (Gordon et al., 2015), a local indicator has been included. This is based on the significant migration premium in the transitions from non- creative occupations to creative ones (see Section 5); instead of the earnings approach, developed in one of the few studies available for large Spanish cities (De la Roca and Puga, 2017). Additionally, the proxy of the number of associations of national scope registered locally has been included.

\section{Stock and flows of creative workers across the urban system}

Considering the potential heterogeneity of creative workers, their personal characteristics are reviewed in Table 1 (for simplicity this part of the analysis ignores the workers' conditions at the beginning of the period). Workers in knowledge-intensive and creative industries are younger and the presence of foreign-born individuals among them is lower than in the rest of the economy. On the contrary, the share of women and workers with university degree is higher. It is important to note that just $28 \%$ of the workers are in creative occupations, confirming the internal labour segmentation within these activities (Sánchez-Moral et al., 2014). On the other hand, workers in creative occupations are older than the rest of workers; the share of women and individuals with university degrees is higher, while the presence of foreign-born workers is lower (Table 2).

According to the aforementioned literature, the observed personal characteristics (i.e. younger workers, lower share of women, more foreign-born individuals) are initially consistent with the greater mobility exhibited by total workers and those in knowledgeintensive and creative industries (see also figures in Tables 2 and 3), In contrast, workers in creative occupation, having a higher education level on average, display lower mobility. This may be connected to the fewer job opportunities for the most qualified workers -and therefore their work migrations- during the economic crisis in Spain. 
Table 1. Personal characteristics of creative workers in 2011 (total country).

\begin{tabular}{|c|c|c|c|}
\hline & Total workers & $\begin{array}{l}\text { Workers in knowledge- } \\
\text { intensive and creative } \\
\text { industries }\end{array}$ & $\begin{array}{l}\text { Workers in } \\
\text { creative } \\
\text { occupations }\end{array}$ \\
\hline $\mathrm{N}$ & 518,626 & 58,699 & 79,195 \\
\hline Average age (years in 2011) & 41.03 & $39.78^{\mathrm{a}}$ & $41.96^{\mathrm{b}}$ \\
\hline Share of women $(\%)$ & 45.27 & $47.37^{\mathrm{a}}$ & $52.58^{\mathrm{b}}$ \\
\hline Share foreign-born workers $(\%)$ & 10.34 & $6.26^{\mathrm{a}}$ & $4.64^{\mathrm{b}}$ \\
\hline Share of creative occupations (\%) & 15.27 & $28.00^{\mathrm{a}}$ & 100.00 \\
\hline Workers with university degree (\%) & 46.31 & $77.50^{\mathrm{a}}$ & $92.47^{\mathrm{b}}$ \\
\hline
\end{tabular}

Source: CSWH.

${ }^{a}$ Significant differences between workers in knowledge-intensive and creative industries and in the rest of the economy.

${ }^{\mathrm{b}}$ Significant differences between workers in creative occupations and in the rest of the occupations (based on ttest; at

$5 \%$ level).

The analysis of the stock and flows of creative workers conducted at municipal level, confirms their strong spatial polarization. More specifically, $54.8 \%$ of workers in knowledgeintensive and creative industries are located in cities with more than 250,000 inhabitants, while Madrid and Barcelona alone concentrate over 35\% (almost 20 points more than their share of total workers). On the contrary, the stock of these workers in cities with less than 40,000 inhabitants represents $12 \%$ of the whole country (less than half of their share of total workers). Their weight in medium-sized cities between 40,000 and 250,000 inhabitants is rather higher, although the differences with respect to the total workers decrease.

Workers in creative occupations display a significantly lower spatial concentration compared with the former group. Thus, Madrid's and Barcelona's share falls below 25\%, while the rest of cities increase their weight with respect to total workers. As previous diagnosis already pointed out, outstanding local trajectories in the knowledge economy can be found beyond big cities; i.e. nodes of decentralized service employment within metropolitan areas, cities specialized in university functions, some former medium-sized industrial cities (Méndez and Sánchez-Moral, 2011).

The consideration of the demographic trajectories in the long term, according to Census data, clarifies the interpretation of workers' flows. Almost all municipalities with fewer than 250,000 inhabitants display a negative net flow of workers in knowledge-intensive and creative industries, with the exception of some growing cities between 40,000 and 100,000 inhabitants. In other words, the role of small cities as source regions of talent is noticeable, especially in the case of those below 40,000 inhabitants, which would have lost around $14.2 \%$ of the total stock in this period; as well as declining cities up to 250,000 inhabitants, which became net losers even though they are net winners of workers in general. Meanwhile, big cities emerge as net receivers, displaying twice the attraction capacity of workers in general.

The flows of workers in creative occupations exhibit similar patterns, albeit the relationship observed between urban size and net flow of workers is somehow blurred. The smaller municipalities and specially declining cities suffer outmigration, while growing cities between 40,000 and 100,000 inhabitants and all those between 100,000 and 1 million became net winners, regardless of their demographic trend. This confirms the attractiveness of medium-sized cities, especially those within major metropolitan areas. On the other hand, the behaviour of the biggest cities deserves special attention. According to the theoretical explanations, the combination of positive net migration of workers overall and negative net migration of high-qualified workers (in both cases in a relatively low proportion) may be 
interpreted as a symptom of some operating escalator effects. In order to test this, we need to discard other explanations, beginning with the scale effects caused by the strong decentralization of employment from big cities towards the metropolitan areas.

The spatial concentration of workers in knowledge-intensive and creative industries across large urban areas increases dramatically with respect to the previous analysis (Table 3). LUAs of more than 1 million inhabitants concentrate more than $52 \%$ of this workforce (far above their share of total workers), while those between 100,000 and 1 million inhabitants allocate another $40 \%$. At the same time, the relationship between urban size and inflows of skilled workers becomes more evident, while the significance of the demographic trends loss relevance at this aggregated level.

The flows of workers in creative occupations exhibit similar patterns, albeit the relationship observed between urban size and net flow of workers is somehow blurred. The smaller municipalities and specially declining cities suffer outmigration, while growing cities between 40,000 and 100,000 inhabitants and all those between 100,000 and 1 million became net winners, regardless of their demographic trend. This confirms the attractiveness of medium-sized cities, especially those within major metropolitan areas. On the other hand, the behaviour of the biggest cities deserves special attention. According to the theoretical explanations, the combination of positive net migration of workers overall and negative net migration of high-qualified workers (in both cases in a relatively low proportion) may be interpreted as a symptom of some operating escalator effects. In order to test this, we need to discard other explanations, beginning with the scale effects caused by the strong decentralization of employment from big cities towards the metropolitan areas.

The spatial concentration of workers in knowledge-intensive and creative industries across large urban areas increases dramatically with respect to the previous analysis (Table 3). LUAs of more than 1 million inhabitants concentrate more than $52 \%$ of this workforce (far above their share of total workers), while those between 100,000 and 1 million inhabitants allocate another $40 \%$. At the same time, the relationship between urban size and inflows of skilled workers becomes more evident, while the significance of the demographic trends loss relevance at this aggregated level.

Once again, the spatial concentration of creative occupations is slightly less pronounced. The biggest LUAs reduce their share up to $42 \%$, while the other categories increase their participation in the country total. Furthermore, when the LUAs of Madrid and Barcelona are observed as a whole, that is considering the number of medium-sized cities within their metropolitan areas, they became net receivers of qualified workers (the negative figures of net flows -or cero values- correspond now to some LUAs affected internally by demographic decline). Moreover, the inspection of the origin and destiny of flows confirms that a large share of these took place between the central city and the rest of the cities within their respective LUAs (41.13\% of arrivals and $52.51 \%$ of departures in the case of Madrid; $40.81 \%$ of arrivals and $39.24 \%$ of departures in the case of Barcelona) (see Figure 1). 
Table 2. Stock and flow of creative workers across municipalities of Spanish urban system (2011).

\begin{tabular}{|c|c|c|c|c|c|c|c|c|c|c|c|c|c|}
\hline \multirow{2}{*}{$\begin{array}{l}\text { Urban strata } \\
\text { (inhabitants) }\end{array}$} & \multirow{2}{*}{$\begin{array}{l}\text { Demographic } \\
\text { trend } \\
(1981-2011)\end{array}$} & \multicolumn{4}{|c|}{ Total workers } & \multicolumn{4}{|c|}{$\begin{array}{l}\text { Workers in knowledge-intensive and } \\
\text { creative industries }\end{array}$} & \multicolumn{4}{|c|}{ Creative occupations } \\
\hline & & Stock $^{(a)}$ & \% Spain & $\begin{array}{l}\text { Net } \\
\text { flow }\end{array}$ & $\%$ Stock & Stock $^{(a)}$ & \% Spain & $\begin{array}{l}\text { Net } \\
\text { flow }\end{array}$ & $\%$ Stock & Stock $^{(a)}$ & \% Spain & $\begin{array}{l}\text { Net } \\
\text { flow }\end{array}$ & $\%$ Stock \\
\hline \multirow[t]{2}{*}{$<40.000$} & Total & $4,178,825$ & 31.57 & $-75,650$ & -1.81 & 191,050 & 12.85 & $-27,075$ & -14.17 & 359,100 & 17.94 & $-14,025$ & -3.91 \\
\hline & Growing & $1,912,125$ & 14.45 & $-3,600$ & -0.19 & 207,100 & 13.93 & 1,950 & 0.94 & 283,850 & 14.18 & 5,125 & 1.81 \\
\hline \multirow[t]{3}{*}{$40.000-100.000$} & Declining & 124,900 & 0.94 & -275 & -0.22 & 9,150 & 0.62 & -425 & -4.64 & 16,175 & 0.81 & -775 & -4.79 \\
\hline & Total & $2,037,025$ & 15.39 & $-3,875$ & -0.19 & 216,250 & 14.55 & 1,525 & 0.71 & 300,025 & 14.99 & 4,350 & 1.45 \\
\hline & Growing & $2,106,100$ & 15.91 & 11,325 & 0.54 & 226,225 & 15.22 & $-3,250$ & -1.44 & 367,475 & 18.36 & 10,475 & 2.85 \\
\hline \multirow[t]{3}{*}{$100.000-250.000$} & Declining & 363,375 & 2.75 & 2,150 & 0.59 & 38,450 & 2.59 & $-1,100$ & -2.86 & 76,275 & 3.81 & 1,100 & 1.44 \\
\hline & Total & $2,469,475$ & 18.66 & 13,475 & 0.55 & 264,675 & 17.80 & $-4,350$ & -1.64 & 443,750 & 22.17 & 11,575 & 2.61 \\
\hline & Growing & $1,996,200$ & 15.08 & 13,575 & 0.68 & 261,775 & 17.61 & 6,100 & 2.33 & 359,725 & 17.97 & 4,600 & 1.28 \\
\hline \multirow[t]{3}{*}{$250.000-1.000 .000$} & Declining & 223,250 & 1.69 & 5,450 & 2.44 & 31,150 & 2.10 & 475 & 1.52 & 49,275 & 2.46 & 1,275 & 2.59 \\
\hline & Total & $2,219,450$ & 16.77 & 19,025 & 0.86 & 292,925 & 19.71 & 6,575 & 2.24 & 409,000 & 20.44 & 5,875 & 1.44 \\
\hline & Growing & $1,476,625$ & 11.16 & 18,925 & 1.28 & 352,850 & 23.74 & 12,725 & 3.61 & 327,050 & 16.34 & $-6,300$ & -1.93 \\
\hline \multirow[t]{2}{*}{$>1.000 .000$} & Declining & 854,200 & 6.45 & 28,100 & 3.29 & 168,775 & 11.35 & 10,600 & 6.28 & 162,425 & 8.12 & $-1,475$ & -0.91 \\
\hline & Total & $2,330,825$ & 17.61 & 47,025 & 2.02 & 521,625 & 35.09 & 23,325 & 4.47 & 489,475 & 24.46 & $-7,775$ & -1.59 \\
\hline
\end{tabular}

Source: Authors' elaboration on Census data and CSWH.

${ }^{\text {a }}$ Stock in 2011. Estimated figures (raising factor of 25).

${ }^{\mathrm{b}}$ Net flow between 2011 and 2007. 
Table 3. Stock and flow of creative workers across Spanish Urban Areas (2011).

\begin{tabular}{|c|c|c|c|c|c|c|c|c|c|c|c|c|c|}
\hline \multirow{2}{*}{$\begin{array}{l}\text { Urban strata } \\
\text { (inhabitants) }\end{array}$} & \multirow{2}{*}{$\begin{array}{l}\text { Demographic } \\
\text { trend } \\
(1981-2011)\end{array}$} & \multicolumn{4}{|c|}{ Total workers } & \multicolumn{4}{|c|}{$\begin{array}{l}\text { Workers in knowledge-intensive } \\
\text { and creative industries }\end{array}$} & \multicolumn{4}{|c|}{ Creative occupations } \\
\hline & & Stock $^{\text {(a) }}$ & $\begin{array}{l}\% \\
\text { Spain }\end{array}$ & $\begin{array}{l}\text { Net flow } \\
\text { (b) }\end{array}$ & $\begin{array}{l}\% \\
\text { Stock }\end{array}$ & Stock $^{(a)}$ & $\begin{array}{l}\% \\
\text { Spain }\end{array}$ & $\begin{array}{l}\text { Net } \\
\text { flow }\end{array}$ & $\begin{array}{l}\% \\
\text { Stock }\end{array}$ & Stock $^{(a)}$ & $\begin{array}{l}\% \\
\text { Spain }\end{array}$ & $\begin{array}{l}\text { Net } \\
\text { flow }\end{array}$ & $\begin{array}{l}\% \\
\text { Stock }\end{array}$ \\
\hline Small Urban Areas & Total & 125,125 & 1.38 & $-3,825$ & -3.06 & 7,825 & 0.60 & -300 & -3.83 & 15,000 & 0.91 & 75 & 0.50 \\
\hline \multirow{3}{*}{$\begin{array}{l}\text { Large Urban Areas } \\
40.000-100.00\end{array}$} & Growing & 792,400 & 8.75 & 3,850 & 0.49 & 71,425 & 5.51 & $-1,150$ & -1.61 & 132,025 & 8.04 & 2,675 & 2.17 \\
\hline & Declining & 28,425 & 0.31 & -550 & -1.93 & 2,025 & 0.16 & -75 & -3.70 & 5,275 & 0.32 & 0 & 0.00 \\
\hline & Total & 820,825 & 9.06 & 3,300 & 0.40 & 73,450 & 5.67 & $-1,225$ & -1.67 & 137,300 & 8.36 & 2,675 & 1.95 \\
\hline \multirow{3}{*}{$\begin{array}{l}\text { Large Urban Areas } \\
100.000-250.000\end{array}$} & Growing & $1,353,225$ & 14.94 & 10,775 & 0.80 & 144,000 & 11.12 & 300 & 0.21 & 227,600 & 13.86 & 4,800 & 2.11 \\
\hline & Declining & 231,125 & 2.55 & $-1,450$ & -0.63 & 28,125 & 2.17 & -850 & -3.02 & 47,350 & 2.88 & -850 & -1.80 \\
\hline & Total & $1,584,350$ & 17.49 & 9,325 & 0.59 & 172,125 & 13.29 & -550 & -0.32 & 27,950 & 16.74 & 3,950 & 1.44 \\
\hline \multirow{3}{*}{$\begin{array}{l}\text { Large Urban Areas } \\
250.000-1.000 .000\end{array}$} & Growing & $2,689,600$ & 29.70 & 12,825 & 0.48 & 312,975 & 24.16 & 3,250 & 1.04 & 450,075 & 27.41 & 4,725 & 1.05 \\
\hline & Declining & 320,575 & 3.54 & 3,950 & 1.23 & 43,900 & 3.39 & 925 & 2.11 & 66,075 & 4.02 & 450 & 0.68 \\
\hline & Total & $3,010,175$ & 33.24 & 16,775 & 0.56 & 356,875 & 27.55 & 4,175 & 1.17 & 516,150 & 31.43 & 5,175 & 1.00 \\
\hline \multirow{3}{*}{$\begin{array}{l}\text { Large Urban Areas } \\
>1.000 .000\end{array}$} & Growing & $3,516,300$ & 38.83 & 50,075 & 1.42 & 685,200 & 52.89 & 24,975 & 3.64 & 698,850 & 42.55 & 2,150 & 0.31 \\
\hline & Declining & - & - & - & - & - & - & - & - & - & - & - & - \\
\hline & Total & $3,516,300$ & 38.83 & 50,075 & 1.42 & 685,200 & 52.89 & 24,975 & 3.64 & 698,850 & 42.55 & 2,150 & 0.31 \\
\hline
\end{tabular}

Source: Authors' elaboration on Census data and CSWH.

${ }^{\mathrm{a}}$ Stock in 2011. Estimated figures (raising factor of 25).

${ }^{\mathrm{b}}$ Net flow between 2011 and 2007. 
Figure 1. Distribution of entries and departures of workers in creative occupations of Madrid and Barcelona cities (2007-2011).
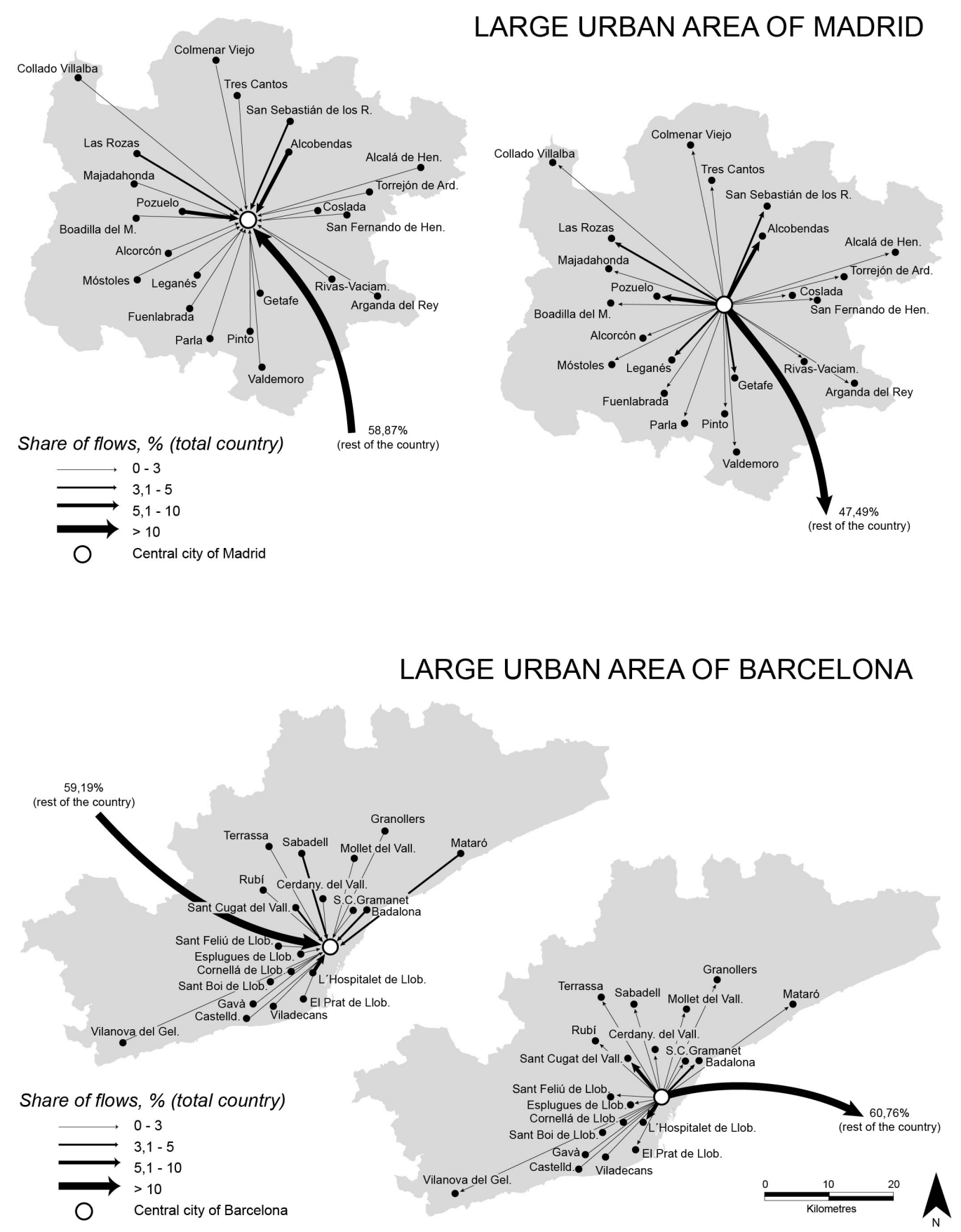

Source: Authors' elaboration on CSWH.

\section{Incidence of escalator/elevator effects in large Spanish cities}

The incidence of escalator/ elevator effects is evaluated in this section. The analysis begins with the study of the very nature of the flows of workers in creative occupations from/to Madrid and Barcelona as 'escalator region' candidates according to previous section. As Table 4 shows, there are some key individual differences (again, the initial conditions of the workers are omitted for now). Workers in creative occupations arriving in these cities are a 
little bit younger (except in the case of Barcelona) and display lower educational and income levels with respect to workers leaving. Even though this evidence supports some of the escalator model forecasts, the range of the differences prevents further conclusions ${ }^{9}$.

The greater differences found between arriving/living workers and staying workers deserve some attention. Our results confirm that talented people may prefer to stay put in a region where they acquired their (tacit) knowledge, skills and networks rather than move to a region with a lack of opportunities (Bontje et al., 2017). Although some of this experience may remain beneficial even when workers relocate, due to its transformation into higher human capital (De la Roca and Puga, 2017), our results suggest that this would also discourage them from moving out of the city too quickly.

Table 4. Characteristics of the migration flows of workers in creative occupations from/to Madrid and Barcelona.

\begin{tabular}{llll}
\hline & $\begin{array}{l}\text { Workers arriving since } \\
\text { City of Madrid }\end{array}$ & $\begin{array}{l}\text { Workers staying } \\
2007-2011\end{array}$ & $\begin{array}{l}\text { Workers leaving } \\
\text { since 2007 }\end{array}$ \\
\hline $\mathrm{N}$ & 1,751 & & \\
Average age (years in 2011) & $36.73^{\mathrm{a}}$ & 11,088 & 2,009 \\
University degree (\%) & $93.26^{\mathrm{a}}$ & $42.86^{\mathrm{a}}$ & $36.92^{\mathrm{a}}$ \\
Income (mean, $€$ ) & $27,515.19^{\mathrm{a}}$ & $95.44^{\mathrm{a}}$ & $93.48^{\mathrm{a}}$ \\
& & $32,852.59^{\mathrm{a}}$ & $28,383.27^{\mathrm{a}, \mathrm{b}}$ \\
City of Barcelona & & \\
$\mathrm{N}$ & 947 & & \\
Average age (years in 2011) & $36.31^{\mathrm{a}}$ & 5,466 & 1,004 \\
University degree $(\%)$ & $92.50^{\mathrm{a}}$ & $42.40^{\mathrm{a}}$ & $36.01^{\mathrm{a}}$ \\
Income (mean, $€$ ) & $27,628.00^{\mathrm{a}}$ & $94.95^{\mathrm{a}}$ & $90.84^{\mathrm{a}}$ \\
\hline
\end{tabular}

${ }^{a}$ Significant differences (at 5\% level) according to t-test on equality of means between arriving/leaving workers and staying workers; ${ }^{\mathrm{b}}$ Significant differences between arriving workers and leaving workers.

Source: CSWH.

To go deeper into the question, occupation transition rates have been calculated from noncreative occupations to creative occupations, following Champion et al. (2013) methodology. These transition rates express the percentage of workers moving up the occupational hierarchy between 2007 and 2011, with respect to total workers in non-creative occupations in 2007. Extending this methodology, the transitions within creative occupations (from 'Technical engineers, qualified assistants' to 'Engineers, university graduates and senior management') have been also calculated ${ }^{10}$. In addition, this new analysis offers the opportunity of searching also for second-order escalators.

The results corroborate that working in one of the biggest cities represents, in general, an advantage for all residents (Table 5). This is reflected in both types of occupational transitions, albeit upward movements within creative occupations are logically rarer. At the same time, the role of big cities as escalator regions for workers arriving from the rest of the country is confirmed, generating a 'migrant premium' in terms of an upgrading from noncreative occupations; when only movements within the creative occupations are considered, then Madrid stand out as the unique significant case at country level.

The disaggregation of data by gender and age allows further conclusions. With regard to transitions from non- creative occupations to creative ones, Madrid and other big cities (Valencia, Seville, Zaragoza, Malaga and Bilbao) would offer greater opportunities for female workers and young workers between 26 and 35 years old, either residents or immigrants. Some of the higher migration premiums are observed in these two categories. In the case of 
transitions within creative occupations, all the residents of Madrid and Barcelona would be specially benefited, as well as the youngest migrants between 26 and 35 years old arriving in Madrid. Nevertheless, some of the higher migration premiums correspond with the age group between 36 and 45 years old, which seems coherent with the stages throughout the careers of the most qualified workers.

Table 5. Occupations transitions for migrants and non-migrants, 2007-2011.

\begin{tabular}{|c|c|c|c|c|c|c|c|}
\hline \multirow[b]{2}{*}{$\begin{array}{l}\text { Gender and } \\
\text { age groups }\end{array}$} & \multirow[b]{2}{*}{ Location } & \multicolumn{3}{|c|}{$\begin{array}{l}\text { From non- creative occupations } \\
\text { to creative occupations }\end{array}$} & \multicolumn{3}{|c|}{$\begin{array}{l}\text { Upgrading within creative } \\
\text { occupations }\end{array}$} \\
\hline & & $\begin{array}{l}\text { Non- } \\
\text { migrants }\end{array}$ & Migrants & $\begin{array}{l}\text { Migrant } \\
\text { Premium }\end{array}$ & $\begin{array}{l}\text { Non- } \\
\text { migrants }\end{array}$ & Migrants & $\begin{array}{l}\text { Migrant } \\
\text { Premium }\end{array}$ \\
\hline \multirow{4}{*}{ All 16-65 } & Madrid & $3.32^{\mathrm{a}}$ & $8.27^{\mathrm{a}}$ & $4.95^{\mathrm{b}}$ & $4.84^{\mathrm{a}}$ & $18.66^{\mathrm{a}}$ & $13.82^{\mathrm{b}}$ \\
\hline & Barcelona & $3.36^{\mathrm{a}}$ & $6.91^{\mathrm{a}}$ & $3.55^{\mathrm{b}}$ & $5.19^{\mathrm{a}}$ & 13.53 & $8.34^{\mathrm{b}}$ \\
\hline & Other large cities & $2.34^{\mathrm{a}}$ & $7.34^{\mathrm{a}}$ & $5.00^{\mathrm{b}}$ & $3.02^{\mathrm{a}}$ & 15.25 & $12.23^{\mathrm{b}}$ \\
\hline & Rest of country & 1.01 & 5.47 & $4.45^{\mathrm{b}}$ & 2.47 & 12.68 & $10.22^{b}$ \\
\hline \multirow{4}{*}{ Males 16-65 } & Madrid & $3.04^{\mathrm{a}}$ & $7.61^{\mathrm{a}}$ & $4.57^{\mathrm{b}}$ & $5.96^{\mathrm{a}}$ & 21.91 & $15.96^{\mathrm{b}}$ \\
\hline & Barcelona & $2.64^{\mathrm{a}}$ & $5.92^{\mathrm{a}}$ & $3.28^{\mathrm{b}}$ & $6.25^{\mathrm{a}}$ & 13.71 & $7.46^{\mathrm{b}}$ \\
\hline & Other large cities & $1.80^{\mathrm{a}}$ & $5.60^{\mathrm{a}}$ & $3.79^{\mathrm{b}}$ & 3.24 & 16.96 & $13.72^{\mathrm{b}}$ \\
\hline & Rest of country & 0.70 & 4.07 & $3.37^{\mathrm{b}}$ & 2.81 & 16.08 & $13.27^{\mathrm{b}}$ \\
\hline \multirow{4}{*}{ Fem. 16-65 } & Madrid & $3.59^{\mathrm{a}}$ & $9.12^{\mathrm{a}}$ & $5.53^{\mathrm{b}}$ & $3.95^{\mathrm{a}}$ & 15.04 & $11.09^{\mathrm{b}}$ \\
\hline & Barcelona & 4.03 & 8.06 & $4.03^{\mathrm{b}}$ & $4.58^{\mathrm{a}}$ & 13.38 & $8.80^{\mathrm{b}}$ \\
\hline & Other large cities & $2.88^{\mathrm{a}}$ & $9.71^{\mathrm{a}}$ & $6.83^{\mathrm{b}}$ & 2.89 & 13.88 & $11.00^{\mathrm{b}}$ \\
\hline & Rest of country & 1.44 & 7.50 & $6.06^{\mathrm{b}}$ & 2.26 & 10.24 & $7.98^{\mathrm{b}}$ \\
\hline \multirow{4}{*}{ All 16-25 } & Madrid & $8.18^{\mathrm{a}}$ & $10.34^{\mathrm{a}}$ & $2.16^{\mathrm{b}}$ & $7.84^{\mathrm{a}}$ & 10.13 & 2.28 \\
\hline & Barcelona & $7.95^{\mathrm{a}}$ & 8.89 & 0.95 & $8.97^{\mathrm{a}}$ & 10.87 & 1.90 \\
\hline & Other large cities & $6.20^{\mathrm{a}}$ & $9.82^{\mathrm{a}}$ & $3.63^{\mathrm{b}}$ & 3.93 & 16.48 & $12.55^{\mathrm{b}}$ \\
\hline & Rest of country & 2.08 & 7.34 & $5.26^{\mathrm{b}}$ & 2.75 & 8.47 & $5.72^{\mathrm{b}}$ \\
\hline \multirow{4}{*}{ All 26-35 } & Madrid & $4.74^{\mathrm{a}}$ & $9.23^{\mathrm{a}}$ & $4.49^{\mathrm{b}}$ & $6.84^{\mathrm{a}}$ & $19.25^{\mathrm{a}}$ & $12.41^{\mathrm{b}}$ \\
\hline & Barcelona & $4.57^{\mathrm{a}}$ & 7.76 & $3.19^{\mathrm{b}}$ & $7.00^{\mathrm{a}}$ & 15.33 & $8.33^{\mathrm{b}}$ \\
\hline & Other large cities & $3.19^{\mathrm{a}}$ & $8.23^{\mathrm{a}}$ & $5.04^{\mathrm{b}}$ & 4.65 & 15.90 & $11.25^{\mathrm{b}}$ \\
\hline & Rest of country & 1.47 & 6.39 & $4.92^{\mathrm{b}}$ & 3.59 & 12.98 & $9.39^{\mathrm{b}}$ \\
\hline \multirow{4}{*}{ All 36-45 } & Madrid & $1.99^{\mathrm{a}}$ & $5.98^{\mathrm{a}}$ & $3.99^{\mathrm{b}}$ & $4.58^{\mathrm{a}}$ & 24.73 & $20.15^{\mathrm{b}}$ \\
\hline & Barcelona & $1.98^{\mathrm{a}}$ & 4.91 & $2.93^{\mathrm{b}}$ & $4.26^{\mathrm{a}}$ & 13.33 & $9.07^{\mathrm{b}}$ \\
\hline & Other large cities & $1.29^{\mathrm{a}}$ & 4.42 & $3.13^{\mathrm{b}}$ & 2.70 & 12.39 & $9.69^{\mathrm{b}}$ \\
\hline & Rest of country & 0.68 & 3.50 & $2.82^{\mathrm{b}}$ & 2.33 & 17.04 & $14.71^{\mathrm{b}}$ \\
\hline \multirow{4}{*}{ All 46-55 } & Madrid & $0.83^{\mathrm{a}}$ & 3.43 & $2.60^{\mathrm{b}}$ & 2.02 & 21.21 & $19.19^{b}$ \\
\hline & Barcelona & $0.67^{\mathrm{a}}$ & 1.96 & $1.29^{\mathrm{b}}$ & $2.83^{\mathrm{a}}$ & 11.76 & $8.93^{b}$ \\
\hline & Other large cities & $0.72^{\mathrm{a}}$ & 3.21 & $2.49^{\mathrm{b}}$ & 1.87 & 12.00 & $10.13^{\mathrm{b}}$ \\
\hline & Rest of country & 0.34 & 2.00 & $1.66^{\mathrm{b}}$ & 1.09 & 9.62 & $8.52^{\mathrm{b}}$ \\
\hline \multirow{4}{*}{ All 56-65 } & Madrid & $0.59^{\mathrm{a}}$ & 3.25 & $2.66^{\mathrm{b}}$ & 0.38 & 0.00 & -0.38 \\
\hline & Barcelona & 0.41 & 0.96 & 0.55 & 1.71 & 0.00 & -1.71 \\
\hline & Other large cities & 0.25 & 1.10 & 0.85 & 0.40 & 33.33 & $32.93^{\mathrm{b}}$ \\
\hline & Rest of country & 0.21 & 1.69 & $1.47^{\mathrm{b}}$ & 0.94 & 9.26 & $8.32^{\mathrm{b}}$ \\
\hline
\end{tabular}

Source: CSWH.

${ }^{a}$ Significant differences between the category and the rest of country.

${ }^{\mathrm{b}}$ Significant differences between migrants and non-migrants (based on t-test; at $5 \%$ level). 


\section{Local drivers of creative worker attraction and retention}

In this final part of our research the stock and flow variables analysed in Section 4 are matched against 22 local indicators to capture the effect of attracting and retaining talent forces (Table 6). The analysis has been conducted at local level to avoid the potential heterogeneity hidden within LUAs and because this is the administrative scale of reference for the most urban policies concerned. Wherever possible, the analysis has been repeated before and after the outbreak of the Spanish economic crisis.

Table 6. Spatial association between the stock (2011) and flows (2007-2011) of creative workers and the local characteristics.

\begin{tabular}{llllc}
\hline & \multicolumn{2}{l}{$\begin{array}{l}\text { Knowledge-intensive } \\
\text { and creative industries }\end{array}$} & \multicolumn{2}{c}{ Creative occupations } \\
\cline { 2 - 5 } Local characteristics & Stock & Net flow & Stock & Net flow \\
\hline Inhabitants 2007(1) & $0.719^{\mathrm{a}}$ & 0.102 & $0.760^{\mathrm{a}}$ & $0.148^{\mathrm{a}}$ \\
Inhabitants 2011(1) & $0.720^{\mathrm{a}}$ & 0.100 & $0.754^{\mathrm{a}}$ & $0.152^{\mathrm{a}}$ \\
Economic Activity Index 2006(2) & $0.795^{\mathrm{a}}$ & 0.137 & $0.821^{\mathrm{a}}$ & $0.211^{\mathrm{a}}$ \\
Economic Activity Index 2012(2) & $0.769^{\mathrm{a}}$ & 0.119 & $0.801^{\mathrm{a}}$ & $0.195^{\mathrm{a}}$ \\
Unemployment rate 2007(2) & $-0.218^{\mathrm{a}}$ & -0.051 & $-0.163^{\mathrm{a}}$ & -0.140 \\
Unemployment rate 2011(2) & $-0.305^{\mathrm{a}}$ & -0.103 & $-0.282^{\mathrm{a}}$ & $-0.148^{\mathrm{a}}$ \\
Share permanent contracts signed in 2007 (3) & $0.160^{\mathrm{a}}$ & 0.096 & 0.102 & $0.151^{\mathrm{a}}$ \\
Share permanent contracts signed in 2011 (3) & 0.046 & 0.035 & 0.039 & 0.074 \\
ISDN \& ADSL/ 1000 inhab. 2012(2) & $0.359^{\mathrm{a}}$ & $0.236^{\mathrm{a}}$ & $0.323^{\mathrm{a}}$ & 0.042 \\
Share employment innovative clusters 2006 (3) & $0.779^{\mathrm{a}}$ & $0.391^{\mathrm{a}}$ & $0.808^{\mathrm{a}}$ & $0.366^{\mathrm{a}}$ \\
Share employment innovative clusters 2009 (3) & $0.561^{\mathrm{a}}$ & $0.346^{\mathrm{a}}$ & $0.696^{\mathrm{a}}$ & $0.337^{\mathrm{a}}$ \\
Housing price 2007 (€/sqm)(4) & $0.273^{\mathrm{a}}$ & -0.022 & $0.236^{\mathrm{a}}$ & 0.142 \\
Housing price 2011 (€/sqm)(4) & $0.269^{\mathrm{a}}$ & 0.030 & $0.241^{\mathrm{a}}$ & 0.104 \\
Share of residents with tertiary education 2011 (1) & $0.656^{\mathrm{a}}$ & $0.364^{\mathrm{a}}$ & $0.625^{\mathrm{a}}$ & $0.193^{\mathrm{a}}$ \\
Share foreign-born residents 2007 (2) & -0.006 & -0.086 & -0.128 & -0.001 \\
Share foreign-born residents 2011 (2) & -0.030 & -0.119 & -0.138 & -0.015 \\
Retail activities Index 2007 (2) & $0.719^{\mathrm{a}}$ & 0.124 & $0.734^{\mathrm{a}}$ & 0.127 \\
Retail activities Index 2011 (2) & $0.712^{\mathrm{a}}$ & 0.113 & $0.730^{\mathrm{a}}$ & 0.119 \\
Employment in culture and leisure 2011 & $0.694^{\mathrm{a}}$ & 0.114 & $0.637^{\mathrm{a}}$ & 0.113 \\
Share of houses $<10$ years in 2011 (1) & $-0.167^{\mathrm{a}}$ & -0.022 & $-0.193^{\mathrm{a}}$ & -0.026 \\
Local escalators indicator 2007-2011 & $0.314^{\mathrm{a}}$ & $0.196^{\mathrm{a}}$ & $0.408^{\mathrm{a}}$ & $0.567^{\mathrm{a}}$ \\
Associations/ 1000 inhab. 2006 (5) & $0.353^{\mathrm{a}}$ & $0.227^{\mathrm{a}}$ & $0.398^{\mathrm{a}}$ & $0.341^{\mathrm{a}}$ \\
\hline So A & &
\end{tabular}

Source: Authors' elaboration on CSWH (2011) and (1) National Institute of Statistics (INE); (2) La Caixa Bank's database;

(3) General Treasury of the Social Security; (4) Spanish Housing Ministry; (5) Spanish Ministry on Interior.

aSignificant Spearman's rho coefficients (at $5 \%$ level).

In general, the behaviour of workers in knowledge-intensive and those in creative occupations is quite similar. On the other hand, the stock variables, which can be interpreted in terms of capacity of retaining talent, tend to be associated more intensively and with a larger number of local characteristics. On the contrary, the net flows, which refer more directly to talent attraction, present weaker associations and with a lower number of local characteristics. At the same time, most of the spatial associations are stable over time (therefore, the following comment are based on initial year values).

The stock of creative workers exhibits one of the most intensive spatial associations with the population of the city (Spearman's Rho $=0.719$ for workers in knowledge intensive and creative industries and 0.760 for workers in creative occupations) and the agglomeration economies captured by the Economic Activity Index ( 0.795 and 0.821 , respectively). These 
associations are maintained during the crisis. In any case, the influence of these variables over the attraction seems limited to workers in creative occupations.

Confirming the transcendence of employment opportunities, the unemployment rate is associated inversely with the stock of workers in knowledge-intensive and creative industries $(-0.218)$ or in creative occupations $(-0.163)$. The economic crisis has intensified this association. In addition, the quality of employment (approached through the share of permanent contracts), which presents some positive associations at the beginning of the period, displayed more ambiguous behaviour during the crisis. On the other hand, the low (positive) association of housing prices with both stocks of creative workers $(0.273$ and 0.236 , respectively) is in line with some mixed results seen in the literature (Bontje et al., 2017). Finally, the supply of high capacity communication networks (RDSI/ADSL) shows a positive correlation with the stocks of workers in knowledge-intensive and creative industries $(0.359)$ and in creative occupations $(0.323)$. The recent attraction of the former workforce also seems to be influenced by this variable $(0.236)$.

The importance of local clusters in terms of employment is positively correlated with the stock of workers in knowledge-intensive and creative industries (0.779) and in creative occupations (0.808) at the beginning of the period. The intense association with the net flows is also among the highest ( 0.391 and 0.366 , respectively). The slightly reduction in the correlation coefficients may be explained by the recent impact of the crisis and the austerity policies on some clusters of the knowledge economy, especially on high-tech industries and cultural sectors (Méndez et al., 2016).

With regard to soft conditions, the share of residents with tertiary education presents a significant positive correlation with both stocks of creative workers ( 0.656 and 0.625 , respectively) and also with their net flows (0.364 and 0.193, respectively). Even though other local characteristics seem not to have an impact on the attraction, they may be favouring the retention of workers. In particular, the strong and positive association of the stock of workers in knowledge intensive and creative industries or in creative occupations with the local importance of retail activities ( 0.719 and 0.734 , respectively) is confirmed; also with cultural and leisure activities (0.694 and 0.637, respectively). Such effects seem to be maintained during the economic crisis. Similarly, the low negative association of houses less than ten years old with the stocks of creative workers (-0.167 and -0.193 , respectively) might be reflecting a higher attractiveness of more consolidated urban sites, although the range of the results prevents further conclusions being reached. Other urban amenities, such as sociocultural diversity, measured by the weight of foreign residents, seem not to have a significant influence.

Finally, confirming the importance of job opportunities in connection with social networks, local escalators are positively correlated with the distribution of creative workers, especially with the stock of these in creative occupations (0.408) as well as with their flows (0.567). On the other hand, the local density of national associations is also positively associated with the stock and flow of workers in knowledge intensive and creative industries ( 0.353 and 0.227 , respectively), as well as in creative occupations (0.398 and 0.341 , respectively).

\section{Conclusions}

Despite the emphasis placed on the attraction and retention of talent processes, little evidence is available as yet (Storper and Scott, 2009; Miguélez and Moreno, 2014). This fact increases the interest of new longitudinal microdata, as the CWHS used in this study, to study patterns and drivers of talent mobility. Moreover, the proposed conceptualization of talent through the 'creative workers' notion has proved to be useful to capture the spatial behaviour of workers 
according to their activities and occupations, albeit more sophisticated ways to integrate both dimension and control workers heterogeneity should be developed in future research. Also the regional dimension of labour markets could be reinforced. Taking into account these limitations, we can now elaborate on the two questions set out at the beginning:

With regard to cities' roles within interregional talent migration patterns, the globalization and new spatial division of labour associated with cultural-cognitive capitalism (Scott, 2008; Paddison and Hutton, 2015) have impacted deeply on the Spanish urban hierarchy. The largest cities reinforce their dominance, concentrating the bulk of workers in the knowledgeintensive and creative industries or in creative occupations. However, the relocation of manufacturing and services activities, as well as of high-level functions, have created opportunities for skilled workers in many metropolitan cities, as well as in some other medium-sized cities exhibiting a relatively successful post-fordist transition. At the same time, many small and declining cities serve as source regions of talent nurturing large, dynamic cities.

Despite the limited differences found between workers in creative occupations arriving and living the main cities, the study of the subsequent occupational mobility of the former group confirms that the biggest cities are acting as escalator regions -even over such a short period of time. These cities propel the careers of the attracted (young) skilled workers, on the basis not only of the generated agglomeration economies but also the job opportunities and social networks existing in their dense urban milieus. If the bias on the traditional dual primacy between Madrid and Barcelona was already detected in favour of the former, for example in terms of global connectivity (Taylor et al., 2011) or the growth of the knowledge and creative economy (Méndez and Sánchez-Moral, 2011), our results suggest the condition of Madrid as the most influential escalator region at country level (if not the only one). Even though this may be interpreted as a reinforcement of the uneven spatial development, the contribution of second-order escalators to a more polycentric knowledge-based development cannot be discarded, as occurred in other countries (Champion et al., 2013).

With respect to the second question, the importance of job opportunities over the qualities of places is confirmed. The economic crisis caused a slowing down of the internal labour migrations due to the destruction of employment countrywide, apart from other effects like the reversal of external immigration or the intensification of the 'brain drain' phenomenon (Hierro and Maza, 2010). As a result, fewer employment opportunities tended to be also more concentrated in the biggest urban areas, where employment creation occurred at the expense, many times, of lower quality work (Miguélez and López-Roldán, 2014). In particular, the mobility of creative workers, which was already quite lower than in other contexts, was reduced and directed mainly towards the major metropolitan area. Within these, some cities have been capable of generating the sort of job opportunities that allow talented workers to advance in their professional careers even during the economic crisis. On the contrary, urban amenities variables seem related to the retention of creative workers during these years, highlighting the influence of retail, cultural and local leisure facilities.

This evidence supports the argument that the priority for Spanish cities should be the recovery of their local economies so that they can support more sustainable job opportunity creation. In this regard, the economic crisis caused major destruction of employment, not only in sectors such as construction, ancillary industries or real estate activities, but also in hightech industries, financial and business services and culture industries, which are essential sources of employment for creative workers. At the same time, they are crucial in firms' ability to be globally competitive, by means for instance of internationalization and innovation strategies. They also make possible a change in the regions' growth patterns 
exhibited before the economic crisis, allowing the fostering of new related specializations. As Storper and Scott (2009) highlight, such upgrading of local productive forces should be based on the selective geographical matching of productive resources, skills and institutions of coordination, which obliges to take into account the differentiated path-dependent trajectories in urban systems. This study has attempted to extend our knowledge in these issues, in order to contribute to developing tailor-made talent attraction and retention strategies.

\section{Acknowledgements}

We would like to thank the anonymous referees for their constructive feedback.

\section{Author's Note}

This research is based on anonymized administrative data provided by the Spanish Social Security system through an annual survey called Continuous Sample of Working Histories (CSWH). In order to assure the confidentiality of individual workers' records, a request must be made to Spain's Dirección General de Ordenación de la Seguridad Social - through its website:

http://www.segsocial.es/Internet_1/Estadistica/Est/Muestra_Continua_de_Vidas_Laborales/in dex.htm - for the original dataset.

\section{Declaration of conflicting interests}

The author(s) declared no potential conflicts of interest with respect to the research, authorship, and/or publication of this article.

\section{Funding}

The author(s) disclosed receipt of the following financial support for the research, authorship, and/or publication of this article: This work was supported by R\&D Spanish project 'CITiTALENT', CSO2016-74888-C4-4-R (AEI/FEDER, UE).

\section{Notes}

1. Also the 'bounded mobility' framework understands that mobility decisions are not isolated decisions, but rather are taken within a predefined geographical and relational context (EFILWC, 2006).

2. Previous tests confirmed that all cities over 40,000 inhabitants are well represented in the CSWH: the average of the differences between total employment and the estimated figures is only $-5.62 \%$, with these residuals showing approximately normal distribution (SánchezMoral, 2017).

3. However, 259,222 people were left out since they have no information either about working location or residence. As a result, the final sample size is 529,424 workers (518,626 workers with complete information about their personal characteristics).

4. Considering the novelty of the analysis, it seems more appropriate to apply the two criteria of sector and occupations separately. This solution prevents the reduction in the sample size that would occur if both visions were to be integrated in the manner of the studies mentioned in Making the 'talent' notion operational through 'creative workers' section. Smaller municipalities would have been specially affected. In addition, this allows for a better understanding of the creative workers' spatial behaviour, although it should be 
remembered that the same individual might belong to both groups.

5. Creative industries: Radio \& TV (NACE codes: 601, 602); Music \& visual and performing arts (900); Video, film, music production and photography (182, 591, 592, 742); Publishing (581, 639); Advertising (731); Software (582, 620); Arts and antiques trade (910, 321, 322, 237); Architecture (711); Design (741). Knowledge-intensive industries: Law and other business services $(691,692,701,702,732,781,823)$; R\&D and higher education (72, 854); Financial services $(64,65,66)$; ICT $(261,262,263,264,265,273,61$, 631).

6. The weight of the self-employed within the creative occupation is initially low, so this limitation should not affect the results. On the other hand, unlike Standard Occupational Classification, this classification makes it difficult to distinguish between 'blue' and 'white collar' workers, forcing a simplification when studying the 'escalator' mechanisms.

7. We use the proxy variable of 'accumulated contribution base' in the CSWH, which is calculated by adding the monthly remunerations entitled by the worker during the year. The range on this variable is truncated between a minimum and a maximum basis established by the Ministry of Employment and Social Security.

8. The Spanish Housing Ministry determined this using a range of socioeconomic variables and cartographic resources. A total of 22 out of 91 LUAs include more than one municipality.

9. The limited number of years of observations available could explain the limited evidence found regarding the differences between arriving and leaving workers. At the same time, the extension of the study to other large cities provided little extra evidence, only having any impact in the cases of Zaragoza and Bilbao.

10. According to Champion et al. (2013), the interpretation of transition rates is based on the comparison between workers' groups and spatial units. Accordingly, our results include ttests on the equality of means.

\section{References}

Becker GS (1964) Human Capital. 1st ed. New York: Columbia University Press for the National Bureau of Economic Research.

Bell D (1973) The Coming of the Post-Industrial Society. New York: Basic Books.

Bontje M, Musterd S and Sleutjes B (2017) Skills and cities: Knowledge workers in Northwest-European cities. International Journal of Knowledge-Based Development 8: $135-153$.

Boschma R and Fritsch M (2009) Creative class and regional growth. Empirical evidence from seven European countries. Economic Geography 85: 391-424.

Champion T, Coombes M and Gordon I (2013) How far do England's second-order cities emulate London as human-capital escalators. SERC Discussion Paper 132. Scotland: Spatial Economics Research Centre.

Cooke TJ (2014) Metropolitan growth and the mobility and immobility of skilled and creative copules across the life course. Urban Geography 35: 219-235.

Cruz S and Texeira AC (2013) Assessing the magnitude of creative employment: A comprehensive mapping and estimation of existing methodologies. European Planning Studies 22: 2172-2209.

Dahl M and Sorenson O (2010) The migration of technical workers. Journal of Urban Economics 67: 33-45.

Da Vanzo J and Morrison PA (1981) Return and other sequences of migration in the United States. Demography 18: 85-101. 
De la Roca J and Puga D (2017) Learning by working in big cities. The Review of Economic Studies 84(1): 106-142.

Delisle FO and Shearmur R (2010) Where does all the talent flow? Migration of young graduates and nongraduates. Canada 1996-2001. Canadian Geographer 54: 305-323.

EFILWC (European Foundation for the Improvement of Living and Working Conditions) (2006) Mobility in Europe. Analysis of the 2005 Eurobarometer Survey on Geographical and Labour Market Mobility. Dublin: EFILWC.

Faggian A and McCann P (2009) Human capital and regional development. In: R Capello and P Nijkamp (eds) Handbook of Regional Growth and Development Theories. Cheltenham: Edward Elgar, pp. 131-151.

Faggian A, McCann P and Sheppard S (2007) Human capital, higher education and graduate migration behaviour. The Annals of Regional Science 40: 461-471.

Faulconbridge J, Beaverstock J and Hall S (2009) The 'War for Talent': The gatekeeper role of executive search firms in elite labour markets. Geoforum 40: 800-808.

Fielding AJ (1992) Migration and social mobility: South East England as an escalator region. Regional Studies 26: 1-15.

Findlay A, Mason C, Harrison R, et al. (2008) 'Getting off the escalator? A study of Scots migration to and from a global city region'. Environment and Planning A 40: 2169-2185.

Florida R (2005) Cities and the Creative Class. New York. Routledge.

Gabe T and Aber JR (2011) Agglomeration of knowledge. Urban Studies 48(7): 1353-1371.

Glaeser EL (2005) Review of Richard Florida's the rise of the creative class. Regional Science and Urban Economics 35(5): 593-596.

Gordon I, Champion T and Coombes (2015) Urban escalators and interregional elevators: The difference that location, mobility, and sectoral specialisation make to occupational progression. Environment and Planning A 47(3): 588-606.

Herbst M and Rok J (2013) Mobility of human capital and its effect on regional economic development. Review of theory and empirical literature. MPRA Paper No. 45755. Warsaw: University of Warsaw.

Hierro M and Maza A (2010) Per capita income convergence and internal migration in Spain: Are foreign-born migrants playing an important role? Papers in Regional Science 89: 89107.

Higgs P, Cunningham S and Bakhsi H (2008) Beyond the Creative Industries: Mapping the Creative Economy in the UK. London: NESTA.

Kempner RT (2008) The talent imperative for older industrial areas. In: RM McGahey and JS Vey (eds) Retooling for Growth. Washington, DC: The Brookings Institution, pp. 61-87.

Krätke S (2010) Creative cities and the rise of the dealer class: A critique of Richard Florida's approach to urban theory. International Journal of Urban and Regional Research 34(4): $835-853$.

Levy F and Murnane RJ (2004) The New Division of Labor. Princenton: Princenton University Press.

Mellander C and Florida R (2009) Human capital or the creative class - Explaining regional development in Sweden. The Annals of Regional Science 92(4): 743-755.

Méndez R and Sánchez-Moral S (2011) Spanish cities in the knowledge economy: Theoretical debates and empirical evidence. European Urban and Regional Studies 18(2): $136-155$.

Méndez R, Sánchez-Moral S and Malfeito G (2016) Employment changes in knowledgebased industries in large urban areas of Spain: Impact of the economic crisis and austerity policies. Environment and Planning C: Government and Policy 34(5): 963-980. 
Miguélez F and López-Roldán P (coordinators) (2014) Crisis. empleo e Inmigración En España. Un análisis De Las Trayectorias Laborales. Barcelona: Universidad Autónoma de Barcelona.

Miguélez E and Moreno R (2014) What attracts knowledge workers? The role of space and social networks. Journal of Regional Science 54(1): 33-60.

Musterd S, Bontje M, Chapain C, et al. (2007) Accommodating creative knowledge. A literature review from a European perspective. Acre Report 1, Amsterdam: University of Amsterdam.

Available

at: http://acre.socsci.uva.nl/results/documents/WP1StateoftheArtversion15mrt2007.pdf

Musterd S, Bontje M and Rouwendal J (eds) (2016) Skills and Cities. New York: Routledge.

Musterd S and Murie A (2010) Making Competitive Cities. Pathways Actors and Policies. London: Blackwell.

Navarro CJ, Mateos C and Rodri'guez MJ (2014) Cultural scenes. The creative class and development in Spanish municipalities. European Urban and Regional Studies 21: 301317.

Paddison R and Hutton T (2015) Cities and Economic Change. Restructuring and Dislocation in the Global Metropolis. London: SAGE.

Putnam R (1993) Making Democracy Work. Civic Traditions in Modern Italy. Princeton: Princeton University Press.

Romer P (1986) Human Capital and Growth: Theory and Evidence. Cambridge: NBER.

Sánchez-Moral S (2017) The mobility of 'creative workers' and their potential contribution to the recovery of old industrial cities in Spain. The Town Planning Review 88: 93-107.

Sánchez-Moral S, Méndez R and Arellano A (2014) Creative economy and employment quality in large urban areas in Spain. Urban Geography 35: 264-289.

Scott AJ (2008) Social Economy of the Metropolis: Cognitive-Cultural Capitalism and the Global Resurgence of Cities. New York: Oxford University Press.

Shapiro JM (2006) Smart cities: Quality of life, productivity, and the growth effects of human capital. Review of Economics and Statistics 88: 324-335.

Shioji E (2001) Composition effect of migration and regional growth in Japan. Journal of Japanese and International Economies 15: 29-49.

Sjaastad LA (1962) The costs and returns of human migration. Journal of Political Economy 70: 80-93.

Stehr N (2002) Knowledge and Economic Conduct. The Social Foundations of the Modern Economy.

Toronto, ON: University of Toronto Press. Storper M and Scott A (2009) Rethinking human capital, creativity and urban growth. Journal of Economic Geography 9(2): 147-167.

Taylor PJ, Ni P, Derudder B, et al. (eds) (2011) Global Urban Analysis: A Survey of Cities in Globalization. London: Earthscan.

Wu W (2005) Dynamic cities and creative clusters. World Bank Policy Research. Working Paper 3509. 